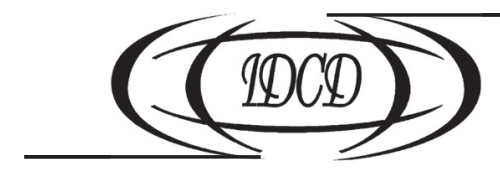

https://doi.org/10.15407/dse2019.02.081

УДК: 314.74(477)

JEL CLASSIFICATION: J61, O15

\title{
І.П. МАЙДАНІК
}

канд. соц. наук, старш. наук. співроб., старш. наук. співроб.

Інститут демографії та соціальних досліджень

імені М.В. Птухи НАН України

01032, Україна, м. Київ, бул. Т. Шевченка, 60

E-mail: Sulamif@online.ua

ORCID 0000-0003-0422-1364

\section{КОНТЕКСТУАЛЬНІ ПАРАМЕТРИ ЗВОРОТНОЇ ТРУДОВОЇ МІГРАЦІЇ В УКРАЇНУ}

Стаття присвячена дослідженню таких важливих параметрів зворотної трудової міграції в Україні як мотиваційна структура, роль членів родини в ухваленні рішення про повернення на батьківщину та рееміграційні стратегії. Робота грунтується на емпіричних даних, зібраних у ході вибіркового обстеження серед зворотних мігрантів ( 739 опитаних) та осіб без міграційного досвіду (509 опитаних), що було проведене протягом грудня 2017p. - липня 2018 р. у Львівській, Тернопільській, Івано-Франківській та Чернівецькій областях. Опитування було складовою частиною проекту «Тимчасова проти постійної міграціï ( Tетроrary versus permanent migration» (TEMPER)), виконаного на замовлення Європейської комісії у межах Сьомої Рамкової програми Свропейського Союзу (РП7). На основі емпіричних даних виявлено, що причинами вибуття за кордон є переважно трудові чинники, а повернення в Україну стимулюють сімейні фактори. Мотиви зворотної міграції з незначними варіаціями майже однакові для різних груп поверненців, незалежно від їхнього віку, статі, типу поселення та інших характеристик. З'ясовано, що на момент прибуття з-за кордонулише чверть усіх поверненців мають наміри залишитись на батьківщині назавжди. Переважна більшість зворотних мігрантів не мають чіткого налаштування на постійне повернення і повну самореалізацію в Україні, вони перебувають у невизначеному положенні стосовно вибору найсприятливішого для себе місия проживання. Така ситуація ставить виклики для демографічної та соціально-економічної безпеки держави і потребує адекватного реагування з боку органів, відповідальних за розробку і реалізацію міграційної політики.

Підтверджено положення нової економіки трудової міграції про те, що рішення як про міграцію за кордон, так і про повернення на батьківщину ухвалює не сам мігрант, а спільно усе домогосподарство. Згідно з результатами обстеження ТЕМПЕР, 40,2 \% опитаних зазначили, що рішення про їх повернення до України ухвалено ними за участю інших осіб. Однак більше половини респондентів, все-таки, самостійно вирішили завершити перебування за кордоном і повернутися. Невелика частка (4,1\%) опитаних поінформували, що рішення про повернення ухвалено повністю іншими особами; такі респонденти були змушені повернутися через сімейні зобов'язання, фінансові чи адміністративні складнощі або були депортовані.

Ключові слова: міграція, трудова міграція, зворотна міграція, циркулярна міграція, мігрант, зворотний мігрант.

( С МАЙДАНІК І.П., 2019

ISSN 2072-9480. Демографія та соціальна економіка, 2019, № 2 (36): 81-95 


\section{И.П. Майданик}

канд. соц. наук, стар. наук. сотруд., старш. науч. сотруд.

Институт демографии и социальных исследований

имени М.В. Птухи НАН Украины

01032, Украина, г. Киев, бул. Т. Шевченка, 60

E-mail: Sulamif@online.ua

ORCID 0000-0003-0422-1364

\section{КОНТЕКСТУАЛЬНЫЕ ПАРАМЕТРЫ ВОЗВРАТНОЙ ТРУДОВОЙ МИГРАЦИИ В УКРАИНУ}

Статья посвящена исследованию таких важных параметров возвратной трудовой миграции в Украине как мотивационная структура, роль членов семьи в принятии решения о возвращении на родину и реэмиграционные стратегии. Работа основана на эмпирических данных, собранных в ходе выборочного обследования среди возвратных мигрантов (739 опрошенных) и лии, без миграционного опыта (509 опрошенных), проведенного в декабря 2017 г. - июле 2018 г. во Львовской, Тернопольской, Ивано-Франковской и Черновицкой областях. Опрос был составной частью проекта «Временная против постоянной миграции» («Temporary versus permanent migration» (TEMPER)) и выполнен по заказу Европейской комиссии в рамках Седьмой рамочной программы Европейского Союза (РП7). На основе эмпирических данных показано, что причинами выбытия за рубежк служат преимущественно трудовые параметры, в то время как возвращение в Украину стимулируют семейные факторы. Мотивы возвратной миграции, с незначительными вариациями, почти одинаковы для разных групп мигрантов, независимо от их возраста, пола, типа населённого пункта и других характеристик. Установлено, что на момент прибытия из-за рубежа лишь четверть возвращенцев намерены остаться на родине навсегда. Подавляющее большинство возвратных мигрантов не имеют четко вырахенного предпочтения к постоянному возвращению и полной самореализации в Украине, они находятся в неопределенном положении относительно выбора наиболее благоприятного для себя места жительства. Такая ситуация ставит вызовы демографической и социально-экономической безопасности государства и требует адекватного реагирования со стороны органов, ответственных за разработку и реализацию миграционной политики.

В статье подтверждено положение новой экономики трудовой миграции о том, что решение как о миграции за рубеж, так и о возвращении на родину принимает не сам мигрант, а все домохозяйство. Согласно результатам обследования ТЕМПЕР, 40,2\% опрошенных приняли решение о возвращении в Украину вместе с другими лицами. Более половины респондентов все жее решили завершить пребывание за границей самостоятельно. 4,1\% опрошенных сообщили, что решение о возвращении принято всеиело другими лицами; такие респонденты были вынуждены вернуться из-за семейных обязательств, финансовых или административных сложностей либо были депортированы.

Ключевые слова: миграция, трудовая миграция, возвратная миграция, циркулярная миграция, мигрант, возвратный мигрант.

\section{I.P. Maidanik}

PhD (Sociology), senior research fellow

Ptoukha Institute for Demography and Social Studies of

National Academy of Science of Ukraine

01032, Ukraine, Kyiv, Taras Shevchenko Blvd., 60

E-mail: Sulamif@online.ua

ORCID 0000-0003-0422-1364

\section{CONTEXTUAL PARAMETERS OF RETURN LABOR MIGRATION TO UKRAINE}

The article is devoted to the study of such important parameters of return labor migration in Ukraine as motivational structure, the role of family in making a return decision and re-emigration strategies. The publication is based on the empirical data collected during the sample survey among the return migrants ( 739 respondents) and persons without migration experience (509 respondents), which was carried out during December 2017 - July 2018 in Lviv, Ternopil, Ivano-Frankivsk and Chernivtsi regions. The survey was a part of the project entitled "Temporary versus permanent migration" (TEMPER) which was supported by the European Commission under the Seventh Framework Program European Union (FP7). The article, based on empirical data, reveals that the reasons to 
go to work abroad are mainly of a labor character, while family factors stimulate returne to Ukraine. Reasons for return migration, with minor variations, are almost identical for different groups of returnees, regardless of age, sex, type of settlement and other characteristics. It was found that at the time of arrival only a quarter of returnees were intended to stay at homeland for good, while the vast majority of return migrants do not have a clear predisposition to permanent stay and full self-realization in Ukraine; they are in an indefinite position regarding the choice of the most favorable place for living. This situation poses challenges for the demographic and socio-economic security of the state and requires adequate response from the authorities responsible for the development and implementation of migration policy.

The article confirms the new economy of labor migration in its belief that the decision of both migration and returning is mostly a joint decision of the whole household. According to the results of the TEMPER survey, 40.2\% of the respondents noted that the decision to return to Ukraine was taken by them with the participation of other persons. However, more than half of respondents have decided to return on their own. A small share (4.1\%) of respondents has informed that the decision to return was made entirely by other persons; such respondents were forced to return due to family obligations, financial or administrative difficulties or were deported.

Keywords: migration, labor migration, return migration, circular migration, migrant, return migrant.

Постановка проблеми та актуальність теми. Різноманітні види, типи та форми міграції, що у кожний конкретний історичний момент набувають різного змістового забарвлення, формують загальне уявлення про калейдоскоп перебігу міграційних процесів. Зворотна міграція з'явилася на дослідницькій арені української науки однією $з$ останніх, тому вона досі не отримала достатньої уваги з боку експертів. Натомість іiі актуальність в умовах депопуляції та нестачі кваліфікованих кадрів на національному ринку праці, знелюднення окремих населених пунктів $є$ незаперечною.

Науковці використовують низку підходів для дослідження процесів зворотної міграції, при цьому вивчення намірів мігрантів щодо запланованої тривалості перебування за кордоном та настанов на повернення можна вважати найпростішим із методів. Такі дослідження здійснюють як на підготовчому етапі міграції, а також під час перебування в іноземній країні. Зазначений підхід викликає нарікання ряду експертів, оскільки первинні наміри особи не завжди відповідають ії подальшій поведінці. Емпіричний матеріал, на якому грунтується ця стаття, окреслює процеси фактичного, уже здійсненого, повернення. Перевагою такої інформації є те, що вона відображає реальні процеси, на противагу уявним міркуванням мігрантів про своє майбутнє.

Проте виключення вивчення намірів із матриці міграційних показників призведе до збіднення наукової дискусії, їх дослідницьке опрацювання варто посилити за рахунок уведення додаткових суміжних індикаторів, на кшталт виявлення рівня кінцевої реалізації початкових намірів, факторів, що визначають їх зміну тощо.

Аналіз останніх досліджень і публікацій. Вагомий дослідницький потенціал мають інтегральні розробки, що ураховують наміри щодо повернення до складу вихідних даних. Одним із таких напрацювань $є$ індекс орієнтації у бік дому (index of home orientation), запропонований румунським вченим Дімітру Санду (Dimitru Sandu) [1, c. 5]. Згаданий показник будується на основі трьох індикаторів: грошових переказів, інтенсивності спілкування з домом за допомогою телефону, е-пошти тощо та наміри повернутися у країну виїзду.

Еволюція категоріального апарату, який використовують для дослідження зворотної міграції, відображає трансформацію внутрішнього змісту цих процесів. У другій половині XX ст. у книзі М. Анвара (М. Anwar), присвяченій мігрантам з Пакистану у Великій Британії [2], було введено у науковий обіг поняття «міф про повернення», яке на тривалий час стало популярним серед зарубіжних дослідників. Пізніше воно зазнало трансформацій, і на його грунті виникли суміжні поняття - «віра у повер- 
нення» та «надії на повернення» [3]. Ж.-П. Кесcаріно (J.-P. Cessarino), який є знаковою фігурою у колі міграційних експертів, запровадив концепцію «підготовки до повернення» (return preparedness) [4], що описує реалізовану поведінку особи і певною мірою протиставляється уявним чи непевним настроям мігрантів щодо повернення, які домінують у поняттях, що наведені раніше.

Українські дослідники активно долучаються до міжнародної наукової дискусії з проблематики зворотної міграції. Грунтовні розробки з цієї тематики, де поглиблено розглянуто особливості вітчизняного контексту, наявні у публікаціях О. Іванкової-Стецюк (O. Ivankova-Stetsyuk), Е. Лібанової (Е. Libanova), О. Малиновської (O. Malinovska), I. Прибиткової (I. Pribitkova), О. Позняка (O. Poznyak), У. Садової (V. Sadova) та інших вчених.

Мета статті - визначити структуру мотиваційних факторів, які стимулюють зворотну трудову міграцію в Україну, оцінити роль домогосподарств у процесі ухвалення рішення про повернення, дослідити рееміграційні настанови поверненців.

Новизна. У статті удосконалено систематизацію та наукове розуміння мотиваційних чинників зворотної міграції українців, уперше виявлено комунікаційні поведінкові зразки у процесі ухвалення рішення про повернення трудових мігрантів в Україну.

Методологія і характеристика вибірки. Основою для написання статті слугує інформація, зібрана у ході дослідження, проведеного в рамках проекту «Тимчасова проти постійної міграції» (ТЕМПЕР) ${ }^{1}$. Обстеження виконано з використанням майже ідентичної анкети в Аргентині, Сенегалі, Румунії та Україні. На території нашої країни у межах дослідження зібрано інформацію про осіб, які здійснили міграції за кордон (в Італію або Польщу) у 1996 р. і пізніше, та повернулися в Україну у 2000 р. і пізніше. Мінімальна тривалість перебування і працевлаштування за кордоном в опитаних осіб - два місяці.

3 метою виключення з обстеження мігрантів, які повернулися в Україну для відвідання родини та друзів або у відпустку, дослідницькою командою було вирішено ввести часовий критерій мінімального строку перебування на батьківщині після повернення - два місяці. 3 огляду на те, що переважна більшість українців, які працюють у двох вищеназваних країнах $\mathrm{CC}$, походять із західних регіонів країни, дослідження організовано у Львівській, Тернопільській, Івано-Франківській та Чернівецькій областях. У кожному з цих регіонів обрано обласний центр та три-чотири райони з населеними пунктами різних типів (місто, село, селище міського типу).

Для пошуку респондентів із міграційним досвідом застосовано метод снігової кулі. Відбір первинних контактів для побудови наступного ланцюга здійснено у неурядових організаціях, які працюють із колишніми мігрантами або займаються питаннями боротьби з торгівлею людьми, на тематичних онлайн форумах, у школах, садочках, сільрадах, релігійних установах тощо. Родзинкою дослідження стала

\footnotetext{
${ }^{1}$ Проект «Тимчасова проти постійної міграції» (Temporary versus permanent migration (TEMPER)) виконано на замовлення Європейської комісії у межах Сьомої Рамкової програми Європейського Союзу (РП7). Для здійснення наукової та адміністративної роботи за проектом було створено консорціум з дев'яти дослідницьких організацій, розташованих у семи країнах світу (Аргентині, Великій Британії, Іспанії, Італії, Румунії, Україні та Франції). Координатором проекту була Національна дослідницька Рада Іспанії (Spanish National Research Council), розташована у Мадриді. Україну у складі виконавчого колективу представляє Інститут демографії та соціальних досліджень імені М.В. Птухи НАН України (ІДСД). Польовий етап емпіричного дослідження в Україні виконав центр «Соціальний моніторинг» на замовлення ІДСД. Строки виконання проекту 01.03.2014 31.08.2018, польового етапу дослідження - грудень 2017 р. - липень 2018 р. Офіційний веб-сайт: http://www. temperproject.eu/
} 
процедура опитування, здійснюваного за допомогою планшета з програмним забезпеченням, розробленим спеціально для цього у рамках проекту ТЕМПЕР.

Для порівняння життєвих траєкторій та поглядів зворотних мігрантів із населенням загалом, опитано також мешканців відповідних областей та населених пунктів без досвіду працевлаштування за кордоном, яким поставлено ідентичні запитання, за винятком блоку питань про міграційний досвід. Респондентів без міграційного досвіду обирали відповідно до загального розподілу населення цільових областей за статтю, віком та типом поселення.

У цій статті викладено результати порівняння поверненців та немігрантів стосовно їхніх (ре)еміграційних настанов.

Загалом у ході дослідження було опитано 739 зворотних мігрантів з Італії та Польщі та 509 осіб без міграційного досвіду. На початковому етапі дослідження було заплановано опитати однакову кількість представників кожної з категорій, однак у ході обстеження виявилося переважання у вибірці мігрантів, які повернулися нещодавно - 2017 року. У зв’язку з цим та для повнішого представлення більш раннього досвіду повернення, було вирішено додатково опитати мігрантів, які повернулися у 2014 р. і раніше.

Дослідження охоплювало осіб віком 20-74 роки. Вибір респондентів такого віку визначено завданнями дослідження та структурою анкети: осіб старших вікових груп (75 років і старші) не розглядали як потенційних респондентів, оскільки анкета містить низку питань про майбутні плани опитаних (інвестиції, наміри щодо майбутнього працевлаштування за кордоном тощо), а майбутнє представників старшого населення у силу вікових особливостей найчастіше наповнено іншим змістом, не пов'язаним 3 продовженням професійної реалізації. Особи, молодші за 20 років, були виключені 3 числа опитаних, оскільки ще не встигли набути достатнього трудового та міграційного досвіду, крім того, існує велика ймовірність, що їх працевлаштування за кордоном є радше частиною сімейного проекту, а не самостійним вибором.

Ураховуючи особливості статевого складу українських мігрантів у різних країнах призначення, вибірку респондентів, які повернулися з Польщі, порівну розподілили між групами чоловіками та жінками, а переважну більшість $(70,2 \%)$ опитаних 3 досвідом працевлаштування в Італії складали жінки.

Виклад основного матеріалу. Причини виїзду за кордон та повернення на батьківщину для респондентів дослідження ТЕМПЕР разюче відмінні: переважна більшість опитаних поїхали за межі України з економічних мотивів (нестабільна робота, низька зарплата, відсутність можливості працевлаштуватися, незадоволеність роботою в Україні тощо), а повернулися - з сімейних (на вимогу членів родини, для возз'єднання сім’ї або у результаті припинення шлюбних стосунків та ін.) (табл. 1). У структурі мотиваційних чинників повернення в Україну велике значення мають також фінансові, адміністративні та емоційні фактори.

Дослідження майже не виявило різниці у структурі причин повернення мігрантів із Польщі та Італії: поверненці з першої з названих країн дещо частіше (на 11,8 в. п.) поверталися в Україну з адміністративних причин, а з другої - з емоційних (на 10,1 в. п.). Остання теза є досить логічною, оскільки за своєю культурою, мовою, кліматом, харчуванням, стилем життя та іншими характеристиками Італія відрізняється від України набагато суттєвіше, аніж Польща.

Причини повернення українських мігрантів на батьківщину певною мірою визначені їхніми віковими характеристиками, які обумовлюють і наповненість 
Таблиия 1. Причини виїзду за кордон та повернення в Україну зворотних мігрантів, \%

\begin{tabular}{|c|c|c|}
\hline \multicolumn{2}{|r|}{ Причини мобільності } & \multirow{2}{*}{$\begin{array}{c}\begin{array}{c}\text { Частка } \\
\text { респондентів, \% }\end{array} \\
8,5\end{array}$} \\
\hline \multirow{7}{*}{ 营 } & $\begin{array}{l}\text { Сімейні фактори (сім’я змушує мігрувати / возз'єднання родини / } \\
\text { щоб діти жили в Європі) }\end{array}$ & \\
\hline & Відсутність можливості працевлаштуватися в Україні & 31,5 \\
\hline & Нестабільна робота, низька зарплата в Україні & 58,1 \\
\hline & Незадоволення моєю роботою в Україні & 14,1 \\
\hline & Отримав(ла) гарну пропозицію роботи за кордоном & 17,6 \\
\hline & Прагнення спробувати щось нове & 8,1 \\
\hline & Інше & 17,2 \\
\hline \multirow{11}{*}{ 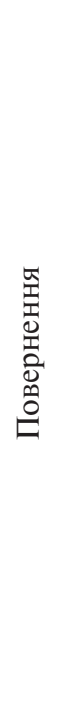 } & Родина в Україні вимагала повернутися & 31,0 \\
\hline & 3 метою одруження, пошуку чоловіка (дружини) & 3,5 \\
\hline & Для возз’єднання / перебування з родиною & 11,8 \\
\hline & Через розлучення & 22,0 \\
\hline & $\begin{array}{l}\text { Закінчення трудової угоди / припинення моєї роботи в Італії / Поль- } \\
\text { щі }\end{array}$ & 14,6 \\
\hline & $\begin{array}{l}\text { Відсутність можливості працевлаштуватися в Італії / Польщі; незадо- } \\
\text { воленість роботою }\end{array}$ & 6,5 \\
\hline & Щоб завершити навчання & 2,6 \\
\hline & $\begin{array}{l}\text { Закінчення терміну дії візи / непоновлення дозволу на проживання / } \\
\text { роботу / вирішення правових питань }\end{array}$ & 17,6 \\
\hline & $\begin{array}{l}\text { Ностальгія: сум за родиною, друзями, харчуванням, стилем життя, } \\
\text { відчуття приналежності до України }\end{array}$ & 19,3 \\
\hline & Проблеми зі здоров'ям & 5,1 \\
\hline & Інше & 20,4 \\
\hline
\end{tabular}

Примітка. Сума часток у табл. 1 більша за $100 \%$, оскільки респонденти могли назвати дві основні причини для від’їду та повернення.

Джерело: результати опитування у рамках проекту ТЕМПЕР.

життєвих смислів у представників різних вікових груп. Наймолодші мігранти (віком 20-29 років) лише у половині випадків повернулися в Україну під впливом сімейних факторів, старші респонденти вказували на відповідну причину у трьох чвертях випадків і більше (табл. 2). Кожен десятий опитаний, який ще не розміняв четвертий десяток, зауважив, що повернувся на батьківщину з огляду на навчальні мотиви, а для інших категорій мігрантів вплив цього чиннику був непомітним або відсутнім, що цілком зрозуміло, адже здобуття освіти є важливим кроком для професійного становлення та отримання певного соціального статусу і відбувається у сучасних українських умовах переважно на ранніх життєвих етапах. Ностальгія, сум за родиною та інші емоційні причини найчастіше спонукали до повернення найстарших та наймолодших респондентів; вага адміністративних мотивів зменшувалася разом зі зростанням віку опитаних; фінансові та трудові чинники помітно частіше називали респонденти віком 20-29 та 40-49 років. 
Таблиия 2. Причини зворотної міграції представників різних статево-вікових та поселенських груп, \%

\begin{tabular}{|l|c|c|c|c|c|c|c|c|}
\hline \multirow{2}{*}{ Причини } & \multicolumn{4}{|c|}{ За віком } & \multicolumn{2}{c|}{ За статто } & \multicolumn{2}{|c|}{$\begin{array}{c}\text { За типом по- } \\
\text { селення }\end{array}$} \\
\cline { 2 - 10 } & $\begin{array}{c}\mathbf{2 0 - 2 9} \\
\text { років }\end{array}$ & $\begin{array}{c}\mathbf{3 0 - 3 9} \\
\text { років }\end{array}$ & $\begin{array}{c}\mathbf{4 0 - 4 9} \\
\text { років }\end{array}$ & $\mathbf{5 0 +}$ & Жінки & $\begin{array}{c}\text { Чолові- } \\
\text { ки }\end{array}$ & Село & Місто \\
\hline Сімейні & 50,0 & 78,4 & 86,3 & 79,5 & 80,0 & 64,7 & 73,5 & 75,0 \\
\hline Фінансові / трудові & 30,2 & 19,5 & 29,1 & 23,7 & 21,8 & 30,2 & 29,3 & 17,0 \\
\hline Навчальні & 11,6 & 2,1 & 0,6 & 0 & 3,8 & 3,1 & 3,6 & 3,4 \\
\hline $\begin{array}{l}\text { Адміністративні / бюро- } \\
\text { кратичні }\end{array}$ & 26,7 & 20,3 & 13,7 & 11,5 & 15,1 & 23,4 & 19,5 & 16,6 \\
\hline Емоційні & 28,5 & 19,5 & 12,0 & 25,0 & 23,0 & 18,0 & 19,9 & 23,0 \\
\hline Стиль життя / смаки & 1,7 & 3,4 & 2,9 & 0,6 & 1,8 & 3,1 & 6,3 & 4,2 \\
\hline Інше & 5,2 & 8,5 & 9,1 & 16,0 & 9,0 & 10,2 & 8,9 & 10,6 \\
\hline
\end{tabular}

Примітка. Сума часток у табл. 2 більша за 100 \%, оскільки респонденти могли назвати дві основні причини для від’їду та повернення.

Джерело: результати опитування у рамках проекту ТЕМПЕР.

Статеві відмінності у мотивації респондентів на повернення є несуттєвими. Вмотивованість до повернення жінок дещо частіше обумовлена емоційною складовою та сімейними факторами (табл. 2), серед останніх найпомітніша різниця (у 9,6 в. п.) між представниками різних статей виявляється у частці опитаних, які причиною повернення на батьківщину назвали розлучення. Представники чоловічої статі трохи частіше вказували на фінансово-трудові та адміністративно-бюрократичні мотиви. Причини повернення респондентів із населених пунктів різних типів майже не відрізняються, єдина незначна відмінність полягає у тому, що селяни дещо частіше (на 12,3 в. п.) повертаються із фінансових та трудових причин.

Загалом, як міграції за кордон, так і повернення в Україну, згідно з результатами обстеження ТЕМПЕР, є значною мірою моновмотивованими: незважаючи на те, що у ході опитування респонденти могли назвати дві причини виїзду та повернення, велика частка опитаних обмежилися озвучуванням лише одного мотиваційного фактору (44,9 \% стосовно міграції та 45,6 \% щодо повернення).

Переважна більшість опитаних задоволені своїм рішенням повернутися в Україну: майже третина $(31,1 \%)$ - задоволені повністю, ще 41,9\% - більшою мірою (рис. 1). Лише 10,0\% респондентів висловили повне або часткове незадоволення своїм рішенням щодо повернення. Різниця між рівнем задоволення від повернення на батьківщину у представників різних вікових та статевих груп виявилася несуттєвою; респонденти з досвідом перебування в Італії висловлювали (повне або часткове) незадоволення від повернення в Україну частіше за поверненців із Польщі (14,1 та 5,9 \% відповідно); майже така сама різниця між частками незадоволених респондентів із сільських населених пунктів та міст (7,8 та 14,0 \% відповідно).

Переважна більшість зворотних мігрантів на момент повернення в Україну мали конкретне уявлення про тривалість майбутнього перебування на батьківщині, лише кожен десятий опитаний із міграційним досвідом заявив про протилежне, при чому зі зростанням віку респондентів питома вага осіб з невизначеними намірами стабільно зменшується. Чверть опитаних $(25,3 \%)$ пов'язували своє повернення 3 


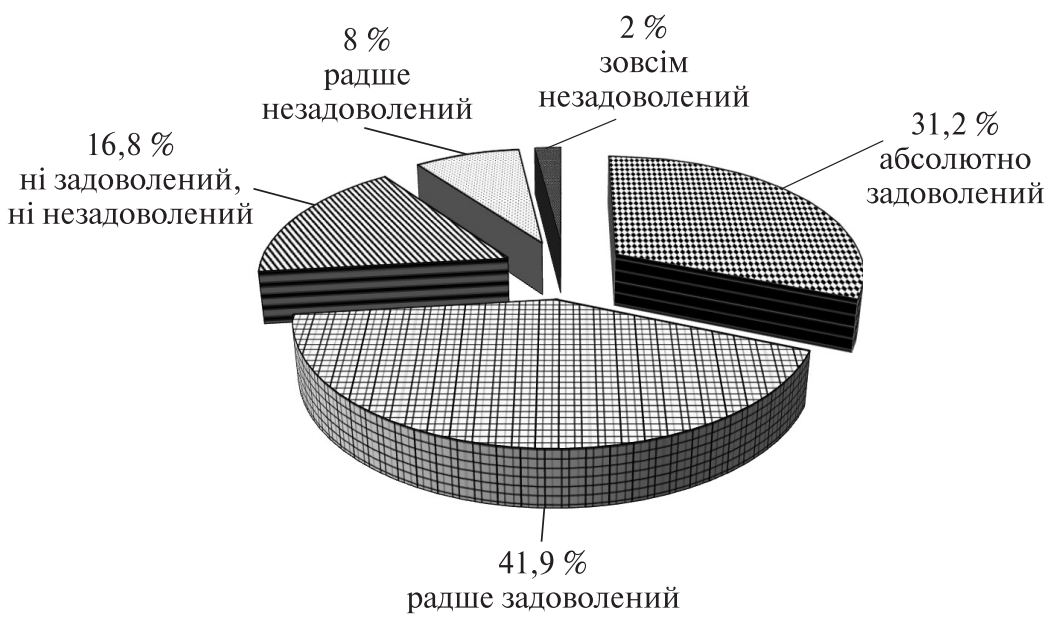

Рис. 1. Розподіл відповідей респондентів на запитання «Чи задоволені ви своїм рішенням повернутися до України?», \%

Джерело: результати опитування у рамках проекту ТЕМПЕР.

завершенням «міграційної кар'єри»; кожен третій $(32,1 \%)$ планував пробути на батьківщині від трьох місяців до року, майже кожен четвертий $(22,6 \%)$ - понад рік, але не завжди. Лише незначний контингент $(2,4 \%)$ мав намір пробути в Україні менше трьох місяців.

Настанови представників різних статей щодо запланованої тривалості перебування в Україні після повернення відрізнялися несуттєво. У розрізі типів населених пунктів - містяни дещо частіше заявляли про свої наміри щодо остаточного повернення, а селяни - про плани пробути на батьківщині понад рік, але не постійно. Серед поверненців із Польщі частка осіб, які планували пробути в Україні від трьох до дванадцяти місяців, була на 9,4 в. п. вищою, ніж тих, хто працював в Італії, і становила $36,8 \%$. Серед останніх було більше осіб, які заявили про остаточне повернення, що підкреслює різницю у характері міграційних поїздок наших співвітчизників до визначених країн, де перебування у Польщі частіше мають короткотривалий та циклічний характер.

Нині у значній кількості теоретичних та практичних розробок з міграційної проблематики наголошено на зв'язках між міграціями та соціально-економічним розвитком, прослідковано роль зворотних мігрантів як можливих агентів позитивних зрушень для країн свого походження. У таких умовах те, що лише чверть усіх поверненців на момент прибуття на батьківщину мають наміри залишитись тут назавжди, показує, що потенціал позитивних змін у результаті зворотної міграції є досить обмеженим. Це є тривожним сигналом для держави, оскільки переважна більшість мігрантів не мають чіткого налаштування на постійне повернення і повну самореалізацію в Україні: вони невизначились із вибором найліпшого для себе місця проживання. 3 іншого боку, така невизначеність є підставою для певного оптимізму, оскільки мігранти виїжджають не назавжди, підтримують міцні зв'язки з батьківщиною, отже є надія на їх повернення та можливість залучити їх до розбудови власного краю. У сучасній міграційній літературі існує поняття «війни або змагання за таланти» [5, с. 43], яке означає змагання між країнами за кваліфікований людський капітал, який на сьогодні є одним із найважливіших факторів прогресу. У такому ракурсі 


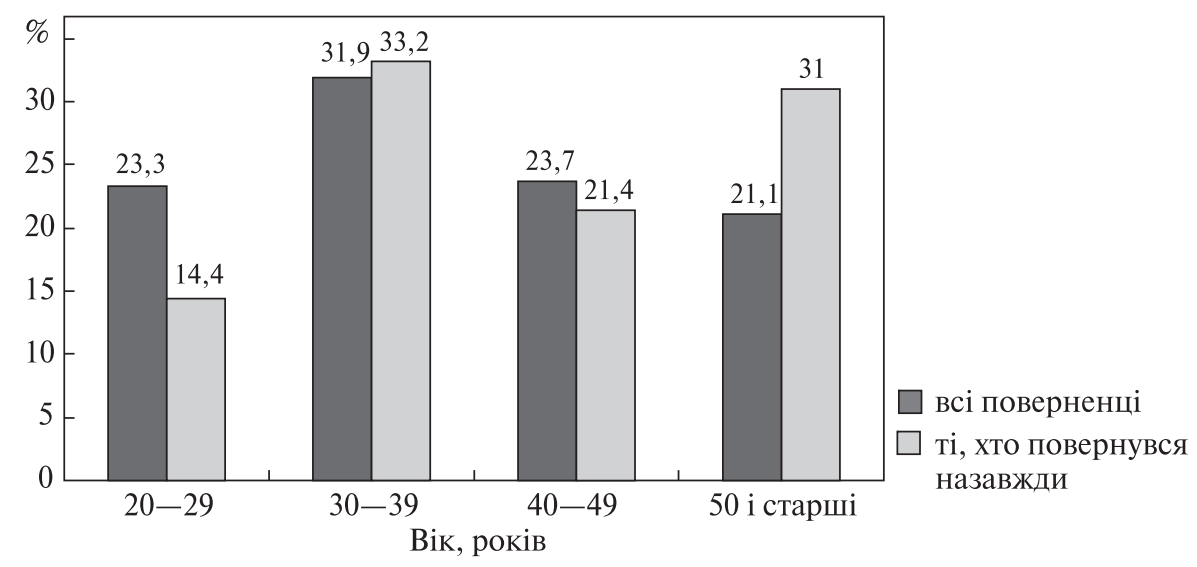

Рис. 2. Віковий розподіл зворотних мігрантів залежно від запланованої тривалості перебування на батьківщині, \%

Джерело: результати опитування у рамках проекту ТЕМПЕР.

найважливіше змагання, яке повинна виграти Україна - це повернути власних громадян, які працюють за кордоном, та забезпечити їм гідні умови праці та проживання, щоб вони, в свою чергу, робили внесок у розбудову країни.

Статева структура всіх зворотних мігрантів та тих, хто повернувся назавжди, майже ідентична: серед обох підгруп переважають жінки (60,1 та 61,5 \% відповідно). Дуже схожим є також розподіл обох категорій залежно від типу населеного пункту, з незначною перевагою селян (64,1 та 58,3 \% відповідно). Серед опитаних, які повернулися назавжди, помітно меншою є частка наймолодших контингентів, і помітно більшою - питома вага найстарших (рис. 2). Середній вік остаточних поверненців є найвищим і складає 42,7 року; наймолодшими (34,3 роки) є ті, хто повернувся на найкоротший термін. Відповідний показник тих опитаних, хто планував після повернення пробути в Україні від трьох до дванадцяти місяців та більше року, але не завжди, є майже однаковим (38,9 та 38,8 року). Також порівняно молодими $(36,4$ роки) виявилися особи, які не визначилися стосовно тривалості свого повернення, очевидно, що багато з них - молодь, у якої ще не сформувалися чіткі преференції стосовно бажаного місця проживання та працевлаштування.

3 огляду на те, що третина остаточних поверненців мають вік понад 50 років, очевидно, що помітну частину їх становлять ті, хто здійснив «повернення через вихід на пенсію» [4, с. 258]. Певна частка старших респондентів можуть здійснювати трудову та соціальну активність на батьківщині, робити важливий внесок у розбудову держави, але загалом інвестиційний, інноваційний та трудовий потенціал цієї категорії осіб є великою мірою вичерпаним.

Прихильники нової економіки трудової міграції стверджують, що рішення як про міграцію за кордон, так і про повернення на батьківщину мігрант не ухвалює самостійно, воно є спільною ухвалою всього домогосподарства. Результати обстеження ТЕМПЕР підтверджують, що така практика $є$ досить поширеною серед українців, оскільки 40,2 \% опитаних зазначили, що рішення щодо їх повернення до України було ухвалено ними за участю інших осіб. Однак більше половини респондентів все-таки самостійно вирішили завершити перебування за кордоном і повернутися. Невелика частка $(4,1 \%)$ опитаних поінформували, що рішення про повернення належало 
цілком іншим особам. Такі респонденти переважно працювали в Італії, декілька 3 них були депортовані, інші були змушені повернутися через сімейні зобов'язання, фінансові чи адміністративні складнощі.

Містяни, жінки та респонденти, які працювали в Італії, більшою мірою враховували думку інших осіб для рішення щодо повернення в Україну, однак ця різниця $є$ незначною у порівнянні з носіями протилежних ознак (6-7 в. п.) (табл. 3). У віковому розрізі опитування показало, що наймолодші респонденти (20-29 років) найчастіше спираються лише на власну думку для ухвалення рішення про повернення, далі зі зростанням віку підвищується роль інших осіб у такому рішенні, яка дещо слабшає для найстарших респондентів (віком 50 років і більше). Таку ситуацію можна пояснити особливостями сімейних зобов’язань у населення різних вікових груп: наймолодші респонденти часто ще не перебувають у шлюбі та не мають дітей, тож почуваються вільними і самостійно визначають напрям своєї життєвої траєкторії; діти найстарших опитаних уже вийшли з малолітнього віку і не потребують батьківського піклування, натомість середній вік є часом найбільш активної побудови сімейних стосунків, народження та виховання чергових поколінь, що впливає і на формування міграційної поведінки. Доволі промовистим виглядає той факт, що як наявність дітей, так і наявність шлюбного партнера в опитаних, впливають на рівень їх самостійності в ухваленні рішення про завершення міграції та повернення на батьківщину, однаково: серед респондентів, які не мають дітей та не перебували у шлюбі на момент опитування, лише трохи більше чверті брали до уваги думку інших осіб стосовно доцільності повернення до України, а одружені респонденти та ті, які мають дітей, врахували думку інших майже у половині випадків.

У регіональному розрізі поведінка респондентів із Чернівецької області щодо самостійності рішення про повернення суттєво відрізняється від опитаних із інших областей. У Львівській, Івано-Франківській та Тернопільській областях близько

Таблиия 3. Розподіл відповідей респондентів на запитання «Рішення про повернення до України було прийнято вами самостійно або за участі інших осіб?» залежно від віку, шлюбного стану та наявності дітей, \%

\begin{tabular}{|l|c|c|c|}
\hline \multicolumn{1}{|c|}{$\begin{array}{c}\text { Варіанти відповіді на аналізоване запитання } \\
\text { анкети }\end{array}$} & $\begin{array}{c}\text { Повністю } \\
\text { мною }\end{array}$ & $\begin{array}{c}\text { Повністю іншими } \\
\text { особами }\end{array}$ & $\begin{array}{c}\text { Мною та } \\
\text { іншими }\end{array}$ \\
\hline \multicolumn{5}{|c|}{ Вікові групи } \\
\hline $20-29$ & 61,60 & 2,30 & 35,50 \\
\hline $30-39$ & 57,20 & 3,40 & 39,00 \\
\hline $40-49$ & 46,30 & 7,40 & 45,70 \\
\hline $50+$ & 55,1 & 3,2 & 41,7 \\
\hline \multicolumn{5}{|c|}{ Перебування у шиюбі } \\
\hline Перебуває у шлюбі & 46,30 & 3,80 & 49,20 \\
\hline Не перебуває у шлюбі & 68,70 & 4,40 & 26,50 \\
\hline \multicolumn{5}{|c|}{ Наявність дітей } \\
\hline С діти & 48,10 & 4,20 & 47,10 \\
\hline Немає дітей & 68,60 & 3,70 & 27,30 \\
\hline
\end{tabular}

Джерело: результати опитування у рамках проекту ТЕМПЕР. 


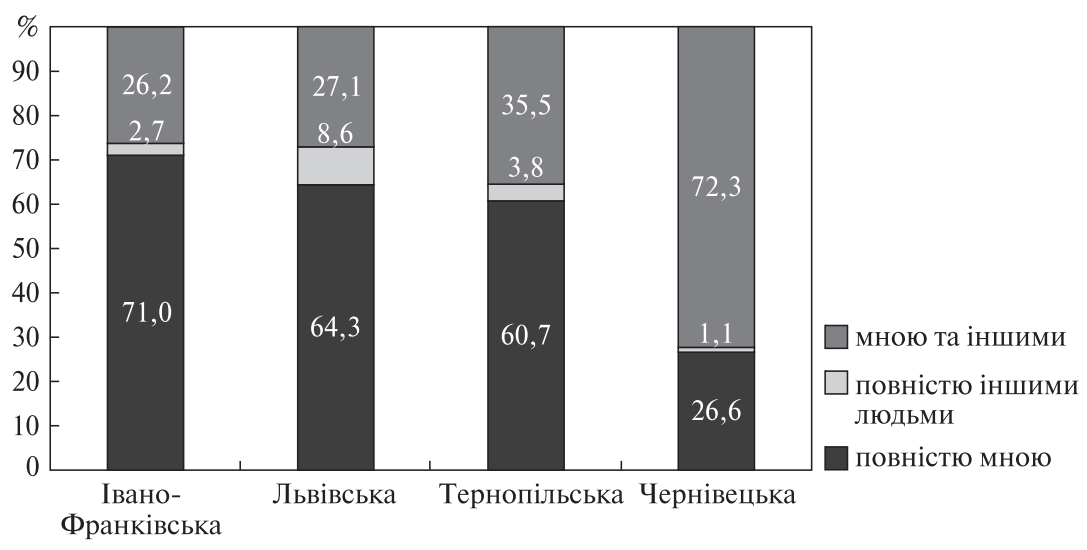

Рис. 3. Розподіл респондентів залежно від області опитування та відповіді на запитання «Рішення про повернення до України було прийнято вами самостійно або за участі інших осіб?», \%

Джерело: результати опитування у рамках проекту ТЕМПЕР.

двох третин опитаних зазначили, що вирішили повертатись самостійно, незначні частки $(2,7-8,6 \%)$ повернулися через рішення інших осіб, інші ухвалювали рішення спільно з іншими особами. Натомість у Чернівецькій області розподіл відповідей був протилежним (рис. 3). За своєю статево-віковою та поселенською структурою, розподілом опитаних між країнами призначення, всі області, охоплені дослідженням, відрізняються несуттєво. Тому пояснити таку відмінність у поведінкових стратегіях щодо повернення серед мешканців визначеного регіону за допомогою інформації лише з аналізованого обстеження неможливо, для вирішення цього питання необхідним є виконання додаткових досліджень.

3 огляду на важливу роль сімейних факторів в ухваленні ключових рішень у міграційних проектах, місце проживання родини респондентів є важливим фактором, що вибудовує контекст повернення. На момент повернення в Україну у більшості респондентів на батьківщині перебували батьки, майже у половини - подружжя, у третини - неповнолітні діти, майже у кожного п'ятого - дорослі нащадки, у досить помітної частини опитаних - брати та сестри (табл. 4). Разом з тим, лише незначні частки респондентів на момент повернення залишили за кордоном членів родини. Така картина ілюструє, що у ситуації вибору майбутнього місця проживання між країною призначення та батьківщиною сімейні зв'язки є потужним фактором притягання до України, акт виїзду за кордон та повернення здійснюється переважно одноосібно. Однак цей висновок стосується лише вибіркової сукупності даного обстеження (тобто тих осіб, які вже повернулися після працевлаштування з-за кордону) і не може поширюватися на всі категорії мігрантів. Зазначена інформація, отримана у ході обстеження ТЕМПЕР, не заперечує поширеності явища возз'єднання українських родин за кордоном, масштабних процесів сімейної міграції, коли за кордон від’їжджають домогосподарства у повному складі. Для аналізу цих процесів необхідно здійснювати спеціальні дослідження, ураховуючи специфіку конкретних міграційних потоків під час формування вибірки.

(Ре)міграційні настрої. Згідно з результатами дослідження ТЕМПЕР, категорія опитаних зворотних мігрантів розділилася на дві майже однакові за розміром групи стосовно їхніх планів поїхати за кордон у наступні п’ять років або залишитися 
Таблиия 4. Розподіл зворотних мігрантів залежно від місця проживання членів родини на момент повернення в Україну, \%

\begin{tabular}{|c|c|c|c|}
\hline \multirow[t]{2}{*}{ Члени родини } & \multirow{2}{*}{$\begin{array}{c}\text { На момент } \\
\text { повернення } \\
\text { проживали } \\
\text { в Україні }\end{array}$} & \multicolumn{2}{|c|}{$\begin{array}{c}\text { На момент повернення проживали } \\
\text { в країні працевлаштування }\end{array}$} \\
\hline & & Так & $\begin{array}{c}\text { Так, але повернулися разом } \\
\text { з респондентом }\end{array}$ \\
\hline Батько & 66,8 & 1,2 & 0,1 \\
\hline Мати & 78,6 & 5,9 & 0,3 \\
\hline Брат(и) & 40,2 & 2,9 & 0,5 \\
\hline Сестра(и) & 41,6 & 4,3 & 0,3 \\
\hline Чоловік / дружина & 47,6 & 3,7 & 2,0 \\
\hline Неповнолітні діти & 34,6 & 0,4 & 0,7 \\
\hline Повнолітні діти & 21,8 & 1,5 & 0,1 \\
\hline Інші особи, важливі для респондента & 80,0 & 23,7 & 1,5 \\
\hline
\end{tabular}

Джерело: результати опитування у рамках проекту ТЕМПЕР.

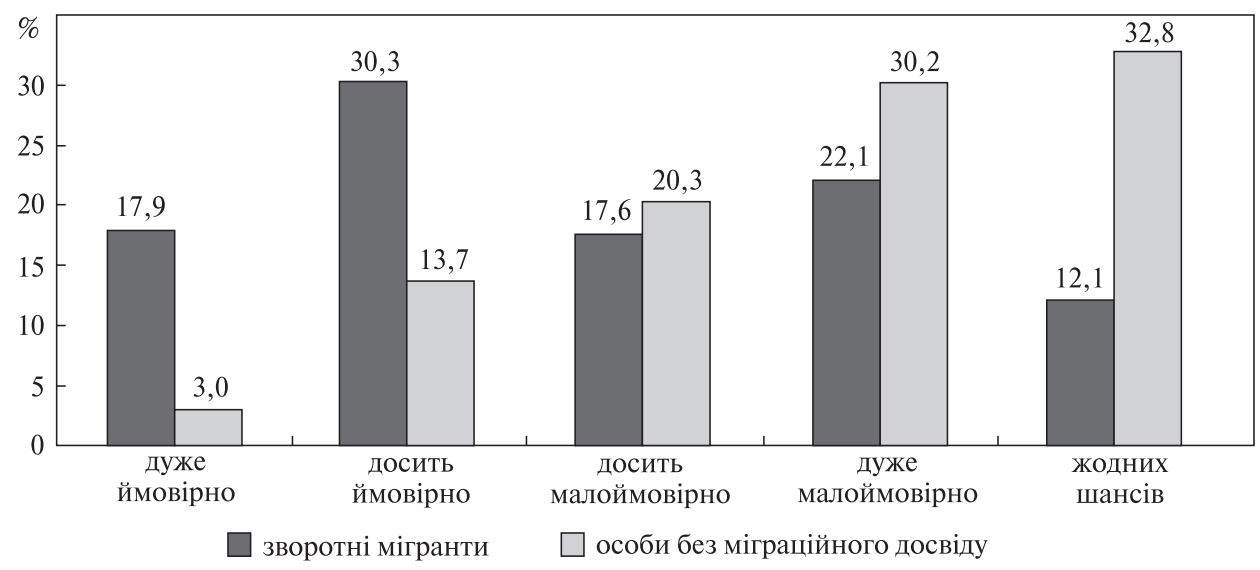

Рис. 4. Розподіл відповідей респондентів на запитання «Наскільки ймовірно те, що ви поїдете за кордон у найближчі два роки?» залежно від наявності міграційного досвіду, \%

Джерело: результати опитування у рамках проекту ТЕМПЕР.

на батьківщині (47,2 та 43,6 \% відповідно); майже кожен десятий не визначився 3 відповіддю на це запитання. Показовим є те, що ситуація щодо міграційних намірів у визначений термін для опитаних осіб, які не мають досвіду працевлаштування за кордоном, кардинально відрізняється: залишитися в Україні планують майже дві третини (65,8 \%), а поїхати за кордон - лише трохи більше чверті (26,9 \%). Такі дані вкотре підтверджують той факт, що в Україні поширеною є практика циркулярних поїздок за кордон, а наявність міграційного досвіду в особи збільшує ймовірність ії майбутнього виїзду з країни на певний термін або назавжди.

Разом з тим, виходячи з наявних ресурсів, ситуації в країнах походження та призначення та інших факторів, досить часто бажання людей розходяться з їхніми фактичними діями. 3 цієї причини у ході дослідження було вирішено уточнити вище 
Таблиця 5. Причини, з яких респонденти налаштовані поїхати за кордон або залишитись в Україні у найближчі два роки, \%

\begin{tabular}{|l|c|c|c|c|}
\hline \multirow{2}{*}{ Причини } & \multicolumn{2}{|c|}{$\begin{array}{c}\text { Причини залишитись } \\
\text { в Україні }\end{array}$} & \multicolumn{2}{c|}{$\begin{array}{c}\text { Причини поїхати за кордон } \\
\text { у найближчі два роки }\end{array}$} \\
\cline { 2 - 5 } & $\begin{array}{c}\text { 3воротні } \\
\text { мігранти }\end{array}$ & Немігранти & $\begin{array}{c}\text { 3воротні } \\
\text { мігранти }\end{array}$ & Немігранти \\
\hline Сімейні & 47,3 & 43,6 & 10,9 & 11,1 \\
\hline Фінансові / трудові & 14,2 & 16,0 & 72,3 & 72,2 \\
\hline Навчальні & 0,4 & 1,1 & - & - \\
\hline Адміністративні, бюрократичні & 4,6 & 2,4 & 0,6 & - \\
\hline Емоційні & 13,9 & 14,5 & 1,8 & 2,6 \\
\hline Спосіб життя / смаки & 4,7 & 6,5 & 11,6 & 10,5 \\
\hline Інше & 14,9 & 14,9 & 2,6 & 2,6 \\
\hline
\end{tabular}

Джерело: результати опитування у рамках проекту ТЕМПЕР.

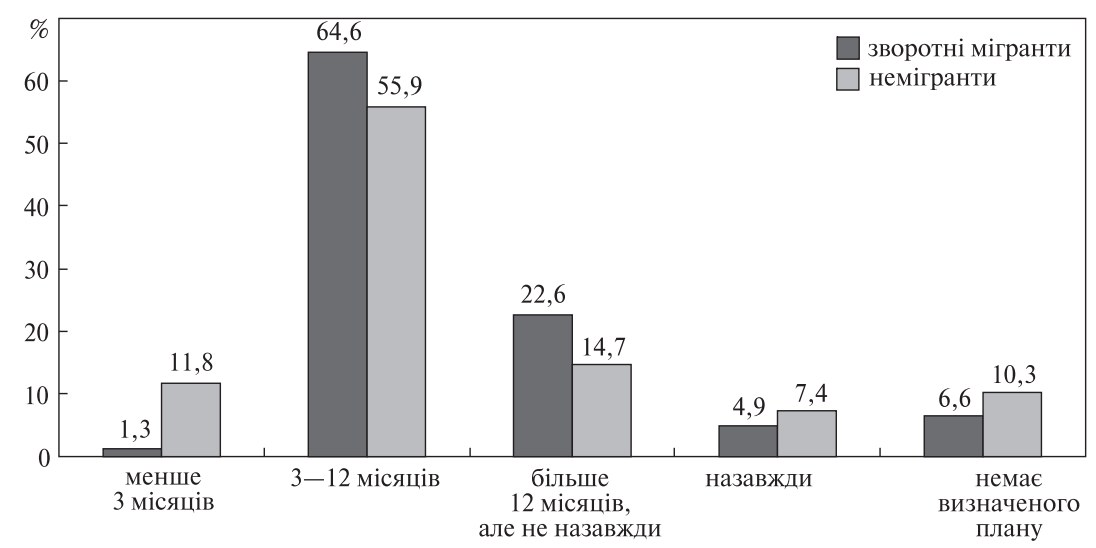

Рис. 5. Розподіл респондентів, які планують поїхати за кордон у наступні два роки, залежно від тривалості запланованого виїзду та наявності міграційного досвіду, \%

Джерело: результати опитування у рамках проекту ТЕМПЕР.

наведені настанови респондентів запитанням щодо реальної ймовірності їх виїзду за кордон протягом найближчих двох років (даний часовий горизонт було зменшено 3 п’яти до двох років, через припущення, що реальні настанови втілюються у життя протягом найближчого часу, а не відкладаються на віддалену перспективу). Незважаючи на зміну фокусу запитання з виявлення бажань до дослідження настанов реальної поведінки та скорочення часового періоду, отримана інформація несподівано виявилася досить схожою: про високу ймовірність виїзду за кордон у найближчі два роки заявили майже половина зворотних мігрантів і лише кожен шостий респондент без міграційного досвіду (рис. 4).

Незважаючи на наявність значної різниці у намірах щодо виїзду за кордон у найближчі роки у зворотних мігрантів та респондентів без міграційного досвіду, структура мотиваційних чинників, що обумовлюють як виїзд за кордон, так і бажання залишитись на батьківщині, в обох категорій опитаних є досить 
однорідною. Переважна більшість тих, хто засвідчив високу ймовірність свого майбутнього виїзду за кордон, сформували такі наміри виходячи з фінансових чи трудових причин, а найважливішими підставами для того, щоб залишитись на батьківщині, є сімейні фактори (табл. 5). Такі дані обстеження збігаються з інформацією, наведеною на початку цієї статті щодо причин уже здійснених міграцій та повернення. Таким чином, попри те, що мова йде про реалізовані чи потенційні міграції для різних категорій респондентів, сімейні зв'язки є фактором, що закріплюють людей у місцях проживання, а трудові змушують до виїзду за кордон.

Серед зворотних мігрантів, які у найближчі два роки планують знову виїхати за кордон, більше половини опитаних $(60,1 \%)$ мають наміри повторити поїздку до тієї країни, де вони працювали минулого разу, кожен п’ятий (20,5 \%) - в іншу європейську державу, кожен десятий ще не визначився. Частка осіб із невизначеними намірами щодо країни майбутнього виїзду серед немігрантів є удвічі більшою, майже дві третини планують виїхати до країн ЕС. Для обох категорій респондентів окреслена майбутня поїздка не має постійного характеру, найчастіше опитані говорять про заплановане перебування за кордоном від трьох місяців до року (рис. 5).

Висновки. Таким чином, зворотна трудова міграція є актуальним та поширеним явищем для України та світу. У різних соціальних, історичних та географічних умовах це явище набуває різного змістовного забарвлення, що відображається у розмаїтті літературних джерел з цієї проблематики та низці теорій, що концептуалізують повернення мігрантів на батьківщину. Особливістю зворотної міграції в українських умовах є їі тимчасовий характер, оскільки велика частка поверненців мають наміри знову поїхати за кордон у майбутньому. Це свідчить про поширеність циркулярної міграції серед населення західних регіонів України, коли акт зворотної міграції слід розглядати не як остаточне фундаментальне рішення, а як певний етап у міграційних проектах населення, про що йдеться у дискурсі транснаціональної теорії міграції. Тимчасові повторювані виїзди за кордон хоча і $є$ більш вигідними для нашої держави з огляду на іiі соціально-економічний та демографічний розвиток, однак також містять низку загроз, зокрема для демографічної безпеки держави через зменшення чисельності населення, оскільки в результаті кожного наступного за черговістю виїзду за кордон мінімум кожен двадцятий мігрант може залишитися там назавжди та в подальшому перевезти туди свою родину.

Причинами виїзду за кордон є переважно трудові чинники, а сімейні фактори стимулюють повернення на батьківщину. Причини зворотної міграції з незначними варіаціями майже однакові для різних груп поверненців, незалежно від їхнього віку, статі, типу поселення тощо.

Визначення основних мотивів зворотної міграції українців, що лежать переважно у сфері сімейних стосунків, можуть мати цінність для розробки Україною плану заходів із заохочення повернення наших співвітчизників. У таких умовах покращання доступу до якісної освіти різних рівнів, охорони здоров'я, дозвілля для дітей слугують не лише фактором розбудови соціальної сфери для всього населення, а є ще й потужним непрямим механізмом міграційної політики у сфері заохочення повернення, недопущення трансформації тимчасової трудової міграції у іiї постійну незворотну форму. Мігранти, які будуть бачити, що їхні діти зростають на батьківщині у сприятливому оточенні, з меншою вірогідністю будуть вивозити їх із собою за кордон, що, у свою чергу, забезпечуватиме зворотність міграційних поїздок. Не заперечуючи важливості непрямих методів впливу, державі, звичайно, не слід нехтувати першопричинами міграцій. Потрібно здійснювати розбудову економічної 
сфери, покращувати можливості працевлаштування на регіональних ринках праці, сприяти зростанню заробітної плати, поліпшувати умови праці та дотримання трудового законодавства.

\section{ЛІТЕРАТУРА}

1. Sandu D. Remittances as Home Orientation Rooted in the Lifeworlds of Immigrants // Central and Eastern European Migration Review. - 2016 July 29. - P. 1-19 [Електронний ресурс]. - Режим доступу: https://www.researchgate.net/publication/305719238_Remittances_as_Home_Orientation_Rooted_in_the_Lifeworlds_of_Immigrants (дата звернення: 20.12.2018).

2. Anwar M. The Myth of Return: Pakistanis in Britain. - London: Heinemann Educational Books, 1979. $-278 \mathrm{p}$.

3. Zetter R. Reconceptualizing the Myth of Return: Continuity and Transition Amongst the GreekCypriot Refugees of 1974 // Journal of Refugee Studies. - Vol. 12, Iss. 1. - P. 1-22 [Електронний pecypc]. - Режим доступу: https://academic.oup.com/jrs/article-abstract/12/1/1/1599932 (дата звернення: 20.12.2018).

4. Cassarino J.-P. Theorising return migration: The conceptual approach to return migrants revisited // International Journal on Multicultural Societies (IJMS), UNESCO, 2004, 6(2), P. 253-279 [Електронний ресурс]. - Режим доступу: https://hal.archives-ouvertes.fr/hal-01237439/document (дата звернення: 20.12.2018).

5. Майданік І.П. Сучасні риси висококваліфікованої міграції в Україні та світі: основні тенденції та структура // Україна: аспекти праці. - 2018. - № 2. - С. 43-49.

6. Малиновська O.A. Еміграція vs Імміграція: напрями та механізми політики репатріації // Демографія та соціальна економіка. - 2019. - № 1 (35). - С. 69-81. - https://doi.org/10.15407/dse2019.01 .069

7. Позняк О.В. Зворотня міграція до України: обсяг і характеристики поверненців // Демографія та соціальна економіка. - 2019. - № 1 (35). - С. 82-96. - https://doi.org/10.15407/dse2019.01.082

\section{REFERENCES}

1. Sandu, D. (2016). Remittances as Home Orientation Rooted in the Lifeworlds of Immigrants. Central and Eastern European Migration Review, 1-19. Retrieved from https://www.researchgate.net/publication/305719238_Remittances_as_Home_Orientation_Rooted_in_the_Lifeworlds_of_Immigrants

2. Anwar, M. (1979). The Myth of Return: Pakistanis in Britain. London: Heinemann Educational Books.

3. Zetter, R. (1999). Reconceptualizing the Myth of Return: Continuity and Transition Amongst the Greek-Cypriot Refugees of 1974. Journal of Refugee Studies, 12 (1), 1-22. Retrieved from https://academic. oup.com/jrs/article-abstract/12/1/1/1599932

4. Cassarino, J.-P. (2004). Theorising return migration: The conceptual approach to return migrants revisited. International Journal on Multicultural Societies (IJMS), UNESCO 2004, 6 (2), 253-279. Retrieved from: https://hal.archives-ouvertes.fr/hal-01237439/document

5. Maidanik, I.P. (2018). Suchasni rysy vysokokvalifikovanoi mihratsii v Ukraini ta sviti: osnovni tendentsii ta struktura [Contemporary features of highly skilled migration in Ukraine and in the world: main trends and structure]. Ukraina: aspekty pratsi - Ukraine: labor aspects, 2, 43-49 [in Ukrainian].

6. Malynovs'ka, O.A. (2019). Emihratsiia vs Immihratsiia: napriamy ta mekhanizmy polityky repatriatsii [Emigration vs Immigration: directions and mechanisms of repatriation policy]. Demohrafiia ta sotsial'na ekonomika - Demography and social economy, 1 (35), 69-81. - https://doi.org/10.15407/dse2019.01.069 [in Ukrainian].

7. Pozniak, O.V. (2019). Zvorotnia mihratsiia do Ukrainy: obsiah i kharakterystyky povernentsiv [Return migration to Ukraine: scales and characteristics of returnees]. Demohrafiia ta sotsial'na ekonomika - Demography and social economy, 1 (35), 82-96. - https://doi.org/10.15407/dse2019.01.082 [in Ukrainian].

Стаття надійшла до редакції журналу 22.03.2019. 